Jurnal Keperawatan Silampari

Volume 2, Nomor 2, Juni 2019

e-ISSN: 2581-1975

p-ISSN: 2597-7482

DOI: https://doi.org/10.31539/jks.v2i2.502

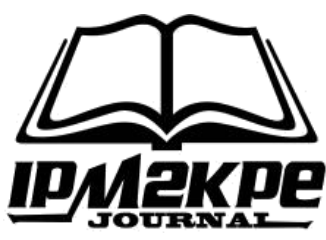

\title{
EFEKTIVITAS WAKTU INJEKSI INSULIN TERHADAP KADAR GLUKOSA DARAH 2 JAM SETELAH MAKAN PADA PASIEN DIABETES MELLITUS TIPE 2
}

\author{
Willady Rasyid ${ }^{1}$, Busjra M Nur ${ }^{2}$, Diana Irawati $^{3}$, Fitrian Rayasari $^{4}$ \\ Program Studi Magister Keperawatan, Universitas Muhammadiyah Jakarta ${ }^{1,2}$ \\ Program Studi Ilmu Keperawatan, Universitas Muhammadiyah Jakarta ${ }^{3}$ \\ Program Studi Keperawatan Medikal Bedah, Universitas Muhammadiyah Jakarta ${ }^{4}$ \\ rasyidwillady@gmail.com ${ }^{1}$
}

\begin{abstract}
ABSTRAK
Tujuan penelitian untuk menganalisis efektivitas waktu injeksi insulin terhadap kadar glukosa darah 2 jam setelah makan. Desain penelitian experimental randomized pretestposttest two group design. Hasil penelitian, kadar glukosa darah intervensi I sebelum makan $(234,88 \mathrm{mg} / \mathrm{dl} \pm 79,68)$ dan 2 jam setelah makan $(246,94 \mathrm{mg} / \mathrm{dl} \pm 76,76)$ dengan $\mathrm{p}$ value 0,000 . Intervensi II $(234,12 \mathrm{mg} / \mathrm{dl} \pm 80,86), 2$ jam setelah makan $(252,35 \mathrm{mg} / \mathrm{dl} \pm$ 78,79 ) denga $\mathrm{p}$ value 0,000 . Selisih kadar glukosa darah intervensi I dan intervensi II $(12,06 \pm 3,96),(18,24 \pm 4,97)$ dengan $\mathrm{p}$ value 0,000 . Pengaruh variabel counfounding BMI terhadap kadar glukosa darah diperoleh ( $\mathrm{p}$ value 0,008 dan 0,037). Simpulan, pemberian injeksi insulin 0-10 menit lebih efektif dibandingan dengan pemberian injeksi insulin 11-20 menit sebelum makan pada pasien DM tipe 2.
\end{abstract}

Kata Kunci: DM Tipe 2, Glukosa Darah 2 Jam setelah Makan, Waktu Injeksi Insulin

\section{ABSTRACT}

The aim of the study was to analyze the effectiveness of insulin injection time on blood glucose levels 2 hours after meals. The research design was experimental randomized pretest-posttest two group design. The results of the study, blood glucose levels of intervention I before meals $(234.88 \mathrm{mg} / \mathrm{dl} \pm 79.68)$ and 2 hours after meals $(246.94 \mathrm{mg}$ / $d l \pm 76.76)$ with a $p$ value of 0,000. Intervention II (234.12 $\mathrm{mg} / \mathrm{dl} \pm 80.86)$, 2 hours after eating $(252.35 \mathrm{mg} / \mathrm{dl} \pm 78.79)$ with a $p$ value of 0,000. Difference in blood glucose levels of intervention I and intervention II (12.06 \pm 3.96$),(18.24 \pm 4.97)$ with a $p$ value of 0.000. The influence of BMI counfounding variables on blood glucose levels was obtained ( $p$ values 0.008 and 0.037). Conclusion, giving insulin injection 0-10 minutes is more effective compared to giving insulin injection 11-20 minutes before meals in patients with type 2 DM.

Keywords: Type 2 diabetes, blood glucose 2 hours after meals, insulin injection time 


\section{PENDAHULUAN}

Perkembangan dunia saat ini menyebabkan perubahan gaya hidup masyarakat. Perubahan gaya hidup seperti pola makan, kurangnya aktivitas fisik dan perilaku tidak sehat dapat menyebabkan berbagai macam masalah kesehatan. Masalah kesehatan yang berhubungan dengan gaya hidup merupakan masalah yang cukup serius yang terjadi di negara maju dan negara berkembang. Salah satunya kasus Diabetes Melitus (DM) (Meetoo, Allen, 2010). Diabetes Mellitus merupakan penyakit kronik yang ditandai dengan hiperglikemia akibat kelainan sekresi insulin, kerja insulin, atau kedua-duanya (ADA 2018). Manifestasi klasik DM adalah polyuria, polydipsia, polyphagia (Black, Hawks, 2014).

Tren kejadian DM menunjukkan sebuah peningkatan yang tidak proporsional di negara berkembang karena transisi demografis yang cepat saat ini dari budaya sampai gaya hidup yang lebih kebarat-baratan dan urbanisasi menurut World Health Organization (WHO, 2016). Secara global sekitar 425 juta $(8,8 \%)$ orang di seluruh dunia diperkirakan penyandang DM tipe 2. Diperkirakan penyandang DM tipe 2 usia 20-79 tahun di Indonesia sebanyak 10,3 juta jiwa. Saat ini Indonesia berada pada peringkat ke-6 sebagai negara dengan jumlah penyandang DM tipe 2 setelah China, India, Amerika, Brazil dan Mexico (IDF, 2017). Dalam KemenKes RI 2014 pada Riskesdas tahun 2013, jumlah DM tipe 2 di Indonesia 6,9 \% atau sekitar 12 juta jiwa. Data sample registration survey tahun 2014 menunjukkan bahwa DM penyebab kematian terbesar nomor 3 di Indonesia dengan persentase sebesar 6,7\%, setelah Stroke $(21,1 \%)$ dan penyakit Jantung Koroner $(12,9 \%)$. Propinsi di Indonesia yang termasuk dalam empat peringkat teratas dengan jumlah kasus DM terbanyak pada usia $\geq 15$ tahun yaitu Daerah Istimewa Yogyakarta (DIY) (2,6\%), DKI Jakarta (2,5\%), Sulawesi Utara (2,4\%), dan Kalimantan Timur (2,3\%) (Kemenkes RI, 2014).

Merujuk pada riskesdas 2013, prevalensi DM tipe 2 di Sumatera Barat tahun 2013 yaitu $1,3 \%$ atau sekitar 44,5 ribu jiwa. Dari data rekam medik RSUD Dr. Achmad Mochtar Bukittinggi yang dirawat inap pada tahun 2016 sebanyak 305 orang penyandang DM tipe 2. Sedangkan pada tahun 2017 sebanyak 372 orang. Terjadinya peningkatan prevalensi DM tipe 2 baik itu didunia maupun di Indonesia di akibatkan ketidakmampuan dalam pengelolaan dan penatalaksanaan DM tipe 2.

Pengelolaan DM tipe 2 bertujuan mengembalikan konsentrasi glukosa darah senormal mungkin agar penyandang DM tipe 2 merasa nyaman dan sehat serta mencegah timbulnya komplikasi mikrovaskuler dan makrovaskuler (Subekti, 2009). Tujuan tersebut dapat tercapai dengan pengendalian glukosa darah yaitu dengan pengeloalaan dan penatalaksanan edukasi, latihan jasmani, terapi farmakologis, diet dan monitoring glukosa darah (Soewondo 2009; Perkeni, 2015). Pengelolaan dan penatalaksanaan pasien yang dirawat dengan DM tipe 2 diperlukan peran perawat dalam pengendalian glukosa darah.

Peran perawat dalam pelayanan pasien dengan DM tipe 2 adalah sebagai pemberi asuhan keperawatan dan sebagai edukator. Sebagai pemberi asuhan keperawatan perawat mengontrol glukosa darah pasien dan mempertahankan glukosa darah pasien mencapai kadar normal. Glukosa darah pada pasien DM tipe 2 dipengaruhi oleh faktor usia, jenis kelamin, obesitas, aktivitas, pola makan, kecemasan dan infeksi dimana akan berdampak pada kontrol glukosa darah. Salah satu cara mengontrol glukosa darah pasien agar tetap normal adalah dengan monitoring glukosa darah dan menggunakan terapi faramakologis berupa injeksi insulin (Subekti, 2009). 
Monitoring glukosa darah dapat dilakukan dengan cara pemeriksaan glukosa darah 2 jam setelah makan. Pemeriksaan ini bertujuan untuk mendeteksi adanya DM atau reaksi hipoglikemik. Standarnya pemeriksaan ini dilakukan minimal 3 bulan sekali. Kadar gula di dalam darah akan mencapai kadar yang paling tinggi pada saat dua jam setelah makan. Normalnya, kadar glukosa dalam darah 2 jam postparndial $<140 \mathrm{mg} / \mathrm{dl}$ (Tandra, 2013). Sedangkan terapi farmakologi salah satunya dengan menggunakan injeksi insulin rapid acting. Insulin rapid acting merupakan jenis insulin analog kerja cepat dengan onset 5-15 menit dengan waktu puncak 1-2 jam dengan lama kerja 4-6 jam (Perkeni, 2015). Insulin jenis rapid-acting memiliki profil sekresi yang sangat mendekati pola sekresi insulin normal atau fisiologis (Rismayanthi, 2011).Waktu yang dianjurkan untuk penyuntikan insulin adalah bersamaan dengan makan atau 0-10 menit sebelum makan (Soegondo, 2009). Selain waktu, lokasi injeksi juga mempengaruhi kerja insulin, penyerapan insulin paling cepat terjadi di daerah abdomen yang kemudian diikuti oleh daerah deltoid, vastus lateralis dan glukteus (Hansen et al, 2007).

Kesalahan waktu pemberian terapi insulin rapid acting cukup sering ditemukan dan menjadi masalah klinis yang penting. Kesalahan tersebut menyebabkan adanya reaksi hiperglikemia dan hipoglikemia. Fenomena yang terjadi jarak penyuntikan insulin dengan waktu makan bervariasi 10-20 menit, seringkali tidak termonitor oleh perawat. Kondisi pasien yang diberikan injeksi insulin dalam rentang waktu tersebut ada beberapa yang mengalami gejala seperti pusing, palpitasi, berkeringat, dan lemas.

\section{METODE PENELITIAN}

Desain penelitian yang digunakan experimental randomized pretest-posttest two group design. Populasi pasien DM tipe 2 rawat inap lantai III dan lantai IV Ambun Suri RSUD Dr. Achmad Mochtar Bukittinggibulan Mei-Juli 2018. Sampel yang digunakan berjumlah 34 respondensesuai dengan kriteria inklusi kemudian di bagi menjadi 2 kelompok. Teknik pengambilan sampel menggunakan teknik probability sampling yaitu simple random sampling.

Variabel independen waktu injeksi insulin, variabel dependen glukosa darah sebelum injeksi insulin dan 2 jam setelah makan dan variabel konfonding usia, jenis kelamin, IMT, riwayat hipertensi dan infeksi.

Injeksi insulin dengan menggunkan jenis insulin Rapid-acting. Pelaksanaan penelitian dengan menjelaskan kepada masing-masing responden tentang prosedur tindakan yang akan dilakukan,lokasi injeski insulin di abdomen dengan jarak injeksi dengan makan 0-10 menit kelompok intervensi I dan 11-20 menit kelompok intervensi II.Pemerikasaan glukosa darah dilkukan sebelum injeksi insulin dan 2 jam setelah makan kemudian dibandingkan apakah ada perbedaan kadar glukosa darah pada kelompok intervensi I dan kelompok intervensi II. Alat pemerikassan glukosa darah menggunakan glucometer accu check.

Analisis statistik yang digunakan untuk variabel counfonding dan nilairata-rata (mean) kadar gula darah sebelum makan dan 2 jam setelah makan digunakan statistik deskriptif. Analisis yang digunakan untuk mengetahui adanya perbedaan kadar gula darah sebelum makan 2 jam setelah makan dalam penelitian ini menggunakan analisis statistik parametris paired $T$ test, sedangkan untuk melhat perbedaan glukosa darah 2 jam kedua kelompok menggunakan Independent $T$ test. Analisis variabel counfonding menggunakan analisis uji ANOVA dan independent T test. 


\section{HASILPENELITIAN}

Penelitian efektifitas waktu injeksi insulin terhadap kadar glukosa darah 2 jam setelah makan pada pasien DM tipe 2 di ruang rawat inap lantai III dan IV Ambun Suri RSUD Dr. Achmad Mochtar Bukittinggi. Penelitian ini dilakukan bulan Mei sampai Juli 2018 pada 34 responden DM tipe 2, dipilih 17 responden sebagai kelompok intervensi I, yaitu kelompok yang diberikan waktu injeksi 0-10 menit sebelum makan dan 17 responden intervensi II yang diberikan waktu injeksi 10-20 menit sebelum makan. Hasil penelitian disajikan dalam bentuk data analisis yaitu karakteristik responden, perubahan kadar glukosa darah sebelum dan 2 jam setelah makan serta perbedaan selisih rata-rata kadar glukosa darah antar kelompok.

Tabel.1

Distribusi Frekuensi Berdasarkan Karakteristik Responden pada Pasien DM Tipe 2

\begin{tabular}{llcccc}
\hline \multirow{2}{*}{ Karakteristik } & \multirow{2}{*}{ Kategori } & \multicolumn{2}{c}{ Intervensi I } & \multicolumn{2}{c}{ Intervensi II } \\
\cline { 3 - 6 } & $26-45$ & $\mathrm{~N}$ & $\%$ & $\mathrm{n}$ & $\%$ \\
\hline Usia & $46-65$ & 12 & 29,4 & 3 & 17,6 \\
& $>65$ & - & 70,6 & 14 & 82,4 \\
& Laki-laki & 6 & - & - & - \\
\hline Jenis Kelamin & Perempuan & 11 & 64.7 & 7 & 41,2 \\
& BB Kurang & 0 & 0 & 0 & 58,8 \\
\hline BMI & BB Normal & 8 & 47,1 & 6 & 0 \\
& Resiko & 6 & 35,3 & 7 & 41,2 \\
& Obesitas & 3 & 17,6 & 4 & 23,5 \\
\hline Riwayat Hipertensi & Tidak & 7 & 41,2 & 8 & 47,1 \\
& Ya & 10 & 58,8 & 9 & 52,9 \\
\hline Infeksi & Tidak & 7 & 41,2 & 10 & 58,8 \\
& Ya & 10 & 58,8 & 7 & 41,2 \\
\hline
\end{tabular}

Hasil penelitian usia pada tabel 1 menunjukkan bahwa usia terbanyak pada kelompok intervensi I yaitu usia 46-65 tahun sejumlah 12 orang dan usia 26-45 tahun sejumlah 5 orang dengan persentase berturut-turut $70,6 \%$ dan $29,4 \%$. Sedangkan pada kelompok intervensi II usia terbanyak pada rentang 46-65 tahun sejumlah 14 orang dan usia 26-45 tahun sejumlah 3 orang dengan persetase berturut-turut $82,4 \%$ dan $17,6 \%$. Hal ini dapat disimpulkan bahwa responden terbanyak dalam penelitian ini adalah responden dengan rentang usia 46-65 tahun.

Hasil penelitian jenis kelamin pada tabel 1 menunjukkan bahwa jenis kelamin terbanyak pada kelompok intervensi I yaitu perempuan sejumlah 11 orang dan laki-laki sejumlah 6 orang dengan persentase $64,7 \%$ dan 35,3\%. Sedangkan pada kelompok intervensi II jenis kelamin terbanyak yaitu perempuan sejumlah 10 orang dan laki-laki sejumlah 7 orang dengan perenstase $58,8 \%$ dan $41,2 \%$. Hal ini menyimpulkan bahwa jenis kelamin terbanyak dalam penelitian ini adalah responden dengan jenis kelamin perempuan.

Hasil penelitian BMI pada tabel 1 menunjukkan bahwa berat badan responden terbanyak pada kelompok intervensi I yaitu dengan berat badan normal sejumlah 8 orang, berat badan resiko obesitas 6 orang dan obesitas sejumlah 3 orang dengan persentase berturut-tururt 47,1\%, 35,3\% dan 17,6\%. Sedangkan pada kelompok intervensi II berat badan responden terbanyak yaitu berat badan resiko obesitas sejumlah 7 orang, berat badan normal 6 orang dan resiko obesitas 4 orang dengan 
persentase berturut-turut $41,2 \%, 35,3 \%$ dan $23,5 \%$. Hal ini dapat disimpulkan bahwa berat badan normal dengan berat badan resiko obesitas tidak jauh berbeda yaitu sejumlah 14 orang dan 13 orang.

Hasil penelitian riwayat hipertensi pada tabel 1 menunjukkan bahwa riwayat hipertensi terbanyak pada kelompok intervensi I sejumlah 10 orang dan tidak hipertensi sejumlah 7 orang dengan persentase 58,8\% dan 41,2\%. Sedangkan pada kelompok intervensi II riwayat hipertensi terbanyak sejumlah 9 orang dan tidak hipertensi 8 orang dengan persentase $52,9 \%$ dan $47,1 \%$. Hal ini dapat disimpulkan bahwa responden dalam penelitian ini sebagian besar mempunyai riwayat hipertensi.

Hasil penelitian infeksi pada tabel 1 menunjukkan bahwa infeksi terbanyak pada kelompok intervensi I yaitu sejumlah 10 orang dan tidak infeksi sejumlah 7 orang dengan persentase $58,8 \%$ dan $41,2 \%$. Sedangkan pada kelompok intervensi II sejumlah 7 orang infeksi dan 10 orang tidak infeksi dengan persentase $41,2 \%$ dan $58,8 \%$. Hal ini dapat disimpukan bahwa responden dengan infeksi dan tidak infeksi berjumlah sama yaitu 17 orang.

Tabel. 2

Rerata Kadar Glukosa Darah Sebelum Makan dan 2PP Kelompok Intervensi I dan II pada Pasien DM Tipe 2

\begin{tabular}{llcccc}
\hline \multicolumn{1}{c}{ Variabel } & Pengukuran & Mean & SD & Min-Mak & 95\% CI \\
\hline GD & Sebelum makan & 234,88 & 79,68 & $130-407$ & $193,91-275,85$ \\
Intervensi I & 2PP & 246,94 & 76,76 & $147-412$ & $207,48-286,41$ \\
& & & & & \\
\hline GD & Sebelum makan & 234,12 & 80,86 & $126-403$ & $192,54-275,69$ \\
Intervensi II & 2PP & 252,35 & 78,79 & $146-426$ & $211,84-292,86$ \\
& & & & & \\
\hline
\end{tabular}

Hasil penelitian kadar glukosa darah Tabel 2 rata-rata kadar glukosa darah pada kelompok intervensi I sebelum makan $(234,88 \pm 79,68)$ dan 2PP $(246,94 \pm 76,76$. Kelompok intervensi II sebelum makan $(234,12 \pm 80,86)$ dan 2 PP $(252,35 \pm 78,79)$.

Tabel. 3

Perbedaan Glukosa Darah Kelompok Intervensi I dan II pada Pasien DM Tipe 2

\begin{tabular}{lcccccc}
\hline \multicolumn{1}{c}{ Variabel } & $\mathrm{n}$ & Mean & SD & SE & CI 95\% & P Value \\
\hline Intervensi I & & & & & & $0,000^{*}$ \\
Sebelum makan & 17 & 234,88 & 79,68 & 19,33 & $193,91-275,85$ & \\
2PP & 17 & 246,94 & 76,76 & 18,62 & $207,48-286,41$ & \\
Selisish & & 12,06 & 3,96 & 0,96 & $14,09-10,02$ & \\
\hline Intervensi II & & & & & & $0,000^{*}$ \\
Sebelum makan & 17 & 234,12 & 80,86 & 19,61 & $192,54-275,69$ & \\
2PP & 17 & 252,35 & 78,79 & 19,11 & $211,84-292,86$ & \\
Selisih & & 18,24 & 4,97 & 1,21 & $20,79-15,68$ & \\
\hline
\end{tabular}

Hasil analisis pada tabel 3 rata-rata kadar glukosa darah pada kelompok intervensi I sebelum makan $(234,88 \pm 79,68)$ dan 2PP $(246,94 \pm 76,76$. Hasil uji statstistik didapatkan nilai $\mathrm{p}=0,000^{*}(\mathrm{p}<0,05)$ yang berarti terdapat perbedaan yang signifikan antara kadar glukosa darah sebelum makan dan 2PP. Kelompok intervensi II sebelum makan $(234,12 \pm 80,86)$ dan $2 \mathrm{PP}(252,35 \pm 78,79)$. Hasil uji statistik didapatkan nilai $\mathrm{p}=0,000^{*}$ 
$(\mathrm{p}<0,05)$ yang berarti terdapat perbedaan yang signifikan antara kadar glukosa darah sebelum makan dan 2PP setelah diberikan intervensi.

Tabel. 4

Perbedaan Selisih Rata-Rata Kadar Glukosa Darah Kelompok Intervensi I dan II pada Pasien DM Tipe 2

\begin{tabular}{lccccc}
\hline \multicolumn{1}{c}{ Variabel } & $\mathrm{N}$ & Selisih Mean & SD & P value & CI 95\% \\
\hline Selisih Mean & & & & & \\
Intervensi I & 16 & 12,06 & 3,96 & $0,000^{*}$ & $14,09-10,02$ \\
Intervensi II & 16 & 18,24 & 4,97 & & $20,79-15,68$ \\
\hline
\end{tabular}

Hasil analisis pada tabel 4 menunjukan selisih rata-rata kadar glukosa darah intervensi I $(12,06 \pm 3,96)$ intervensi II $(18,24 \pm 4,97)$. Hasil uji statastistik didapatkan $p=$ $0,000 *$ ( $<<0,05$ ) yang berarti terdapat perbedaan yang signifikan antara kadar glukosa darah setelah intervensi pada kelompok intervensi I dan intervensi II.

Tabel. 5

Pengaruh Counfounding terhadap Glukosa Darah 2 Jam Setelah Makan pada Kelompok Intervensi I pada Pasien DM Tipe 2

\begin{tabular}{lccccc}
\hline \multicolumn{1}{c}{ Variabel } & Mean & SD & SE & P value & n \\
\hline Usia & & & & & \\
$26-45$ & 283,40 & 101,25 & 45,28 & 0,217 & 5 \\
$46-65$ & 231,75 & 63,14 & 18,23 & & 12 \\
$>65$ & & & & & 0 \\
\hline Jenis Kelamin & & & & & \\
Laki-Laki & 246,17 & 84,59 & 23,39 & 0,977 & 6 \\
Perempuan & 247,36 & 76,47 & 27,04 & & 11 \\
\hline BMI & 0 & & & & \\
BB Kurang & 203,13 & 38,87 & 13,73 & 0,008 & 8 \\
BB Normal & 317,50 & 79,53 & 32,47 & & 6 \\
BB Resiko & 22,67 & 50,33 & 29,06 & & 3 \\
Obesitas & & & & & \\
\hline Riwayat Ht & 254,43 & 92,40 & 34,94 & 0,748 & 7 \\
Tidak & 241,70 & 68,57 & 21,68 & & 10 \\
Ya & & & & & \\
\hline Infeksi & 252,43 & 76,55 & 28,93 & 0,814 & 7 \\
Tidak & 243,10 & 80,79 & 25,55 & & 10 \\
Ya & & &
\end{tabular}

Berdasarkarkan tabel 5 uji counfounding terhadap kadar glukosa darah 2PP pada intervensi I menunjukkan responden yang berusia 26-45 tahun rata-rata kadar glukosa darah 2 jam setelah makan $(283,40 \pm 101,25)$. Usia 46-65 tahun $(231,75 \pm 63,14)$. Hasil uji statistik menunjukkan nilai $\mathrm{p}=0,217(\mathrm{p}<0,05)$. Responden dengan jenis kelamin lakilaki rata-rata kadar glukosa darah $(246,17 \pm 84,59)$. responden perempuan $(247,36 \pm 76,47)$. Hasil uji statistic menunjukkan nilai $\mathrm{p}=0,977(\mathrm{p}<0,05)$ responden dengan IMT normal rata-rata kadar glukosa darah $(203,13 \pm 38,87)$ responden berat badan dengan resiko $(317,50 \pm 79,53)$ obesitas $(222,67 \pm 50,33)$. Hasil uji statistic menunjukkan nilai $\mathrm{p}=0,008(\mathrm{p}<0,05)$. Responden dengan riwayat hipertensi rata-rata memiliki kadar glukosa darah $(241,70 \pm 68,57)$ tidak mempunyai riwayat hipertensi $(254,43 \pm 92,40)$. Hasil uji statistic menunjukkan nilai $\mathrm{p}=0,748(\mathrm{p}<0,05)$. Responden 
dengan infeksi rata-rata kadar glukosa darah $(243,10 \pm 80,79)$. responden yang tidak infeksi $(252,43 \pm 76,55)$. Hasil uji statistic menunjukkan nilai $\mathrm{p}=0,814(<0,05)$.

Tabel. 6

Pengaruh Counfounding terhadap Kadar Glukosa Darah 2 Jam Setelah Makan pada Kelompok Intervensi II pada Pasien DM Tipe 2

\begin{tabular}{lccccc}
\hline \multicolumn{1}{c}{ Variabel } & mean & SD & SE & P value & $\mathrm{n}$ \\
\hline Usia & & & & & \\
$26-45$ & 308,67 & 70,32 & 40,60 & 0,180 & 3 \\
$46-65$ & 240,29 & 77,40 & 20,69 & & 14 \\
$>65$ & 0 & 0 & 0 & & \\
\hline Jenis Kelamin & & & & & \\
Laki-Laki & 252,57 & 88,53 & 33,46 & 0,993 & 7 \\
Perempuan & 252,20 & 76,22 & 24,10 & & 10 \\
\hline BMI & & & & & \\
BB Kurang & 0 & 0 & 0 & & 0 \\
BB Normal & 202,33 & 51,47 & 21,01 & 0,037 & 6 \\
BB Resiko & 252,57 & 67,39 & 25,47 & & 7 \\
Obesita & 327,00 & 84,70 & 42,35 & & 4 \\
\hline Riwayat Ht & & & & & \\
Tidak & 241,38 & 59,57 & 21,06 & 0,604 & 8 \\
Ya & 262,11 & 95,30 & 31,77 & & 9 \\
\hline Infeksi & & & & & \\
Tidak & 257,90 & 54,33 & 17,18 & 0,771 & 10 \\
Ya & 244,43 & 109,54 & 41,40 & & 7 \\
\hline
\end{tabular}

Berdasarkarkan tabel 6 uji counfounding terhadap selisih kadar glukosa darah pada intervensi I menunjukkan responden yang berusia 26-45 tahun rata-rata kadar glukosa darah 2 jam setelah makan adalah $(308,67 \pm 70,32)$. respoden usia 46-65 tahun $(240,29 \pm 77,40)$. Hasil uji statistik menunjukkan nilai $\mathrm{p}=0,180(\mathrm{p}<0,05)$. Responden dengan jenis kelamin laki-laki rata-rata kadar glukosa darah 2 jam setelah makan $(252,57 \pm 88,53)$ responden perempuan $(252,20 \pm 76,22)$. Hasil uji statistic menunjukkan nilai $\mathrm{p}=0,993(\mathrm{p}<0,05)$ Responden dengan BMI normal rata-rata kadar glukosa darah 2 jam setelah makan $(202,33 \pm 51,47$ responden berat badan dengan resiko $(252,57 \pm 67,39)$ obesitas $(327,00 \pm 84,70)$. Hasil uji statistic menunjukkan nilai $\mathrm{p}=0,037(\mathrm{p}<0,05)$. Responden dengan riwayat hipertensi rata-rata kadar glukosa darah 2 jam setelah makan $(262,11 \pm 95,30)$ responden tidak riwayat hipertensi $(241,38 \pm 59,57)$. Hasil uji statistik menunjukkan nilai $\mathrm{p}=0,604(\mathrm{p}<0,05)$ Responden dengan infeksi rata-rata kadar glukosa darah 2 jam setelah makan $(244,43 \pm 109,54)$ tidak mengalami infeksi $(257,90 \pm 54,33)$. Hasil uji statistic menunjukkan nilai $\mathrm{p}=0,771(\mathrm{p}<0,05)$.

\section{PEMBAHASAN}

Hasil analisis univariat variabel usia menunjukkan bahwah sebagian besar responden pada kedua kelompok intervensi adalah responden dengan usia rentang 46-65 tahun. Hasil analisis bivariat menunjukkan bahwa tidak ada pengaruh usia terhadap kadar glukosa darah 2 jam setelah makan pada kelompok intervensi I dan intervensi II.

Peningkatan usiadiatas 30 tahun, hal ini karena adanya penurunan anatomis, fisiologis, dan biokimia. Perubahan dimulai dari tingkat sel, kemudian berlanjut pada tingkat jaringan dan akhirnya pada tingkat organ yang dapat mempengaruhi homeostasis. Selain itu pada individu yang berusia lebih tua terdapat penurunan 
aktivitas mitokondria di sel-sel otot sebesar 35\%. Hal ini berhubungan dengan peningkatan kadar lemak di otot sebesar $30 \%$ dan memicu terjadinya resistensi insulin (Damayanti, 2015). Dari data WHO didapatkan bahwa setelah mencapai usia 30 tahun, kadar glukosa darah akan naik 1-2 mg\%/tahun pada saat puasa dan akan naik sebesar 5,6-13 mg\%/tahun pada 2 jam setelah makan (Kurniawan,2010). Lebih dari 80\% dari 184 juta orang dengan DM berada pada rentang umur ini (IDF, 2017).

Hasil penelitian ini sesuai dengan hasil penelitian Trisnawati, Setyorogo (2013) bahwa usia $\geq 45$ tahun banyak mengalami DM tipe 2. Lebih lanjut Irawan (2010) sekitar 65,7\% mengalami DM berusia lebih dari 45 tahun. Dari analisis bivariat terlihat bahwa risiko usia lebih dari 45 tahun berisiko 14,99 kali untuk menderita DM (Irawan,2010). Hasil penelitian Rachmawati (2015) dari 195 responden didapatkan sejumlah 64 orang berusia 46-55 tahun.

Hasil analisis univariat jenis kelamin sebagian besar responden pada kedua kelompok intervensi adalah dengan jenis kelamin wanita. Hasil uji statistik analisis bivariat menunjukkan bahwa tidak ada pengearuh jenis kelamin terhadap kadar glukosa darah 2 jam setelah makan yang diberikan injeksi insulin 0-10 menit dan 11-20 menit.

Wanita lebih berisiko mengidap DM karena secara fisik wanita memiliki peluang peningkatan indeks masa tubuh yang lebih besar. Sindroma siklus bulanan (premenstrual syndrome), pascamenopouse yang membuat distribusi lemak tubuh menjadi mudah terakumulasi akibat proses hormonal tersebut sehingga wanita berisiko menderita DM tipe 2 (Irawan, 2010). Timbunan lemak bebas yang tinggi dapat menyebabkan meningkatnya free fatty acid (FFA). Peningkatan FFA akan menurunkan translokasi transporter glukosa ke membran plasma, dan menyebabkan terjadinya resistensi insulin pada jaringan otot dan adipose (Teixeria-Lemos dkk, 2011).

Hasil penelitian ini sesuai dengan teori bahwasanya perempuan lebih banyak mengalami DM di banding dengan laki-laki ini dikerenakan akibat dari peningkatan indek masa tubuh dan perubahan hormonal selama kehamilan, massa haid dan masa pasca monopouse. Penelitian sejalan penelitian Widodo (2016) dari 48 responden menunjukkan hasil bahwa sebagian besar responden yang memiliki peningkatan kadar glukosa darah adalah perempuan sebanyak 66,7\%. Penelitian yang dilakukan oleh Irawan (2010) prevalensi DM tipe 2 lebih tinggi pada perempuan yaitu 6,71\%, sedangkan pada laki-laki prevalensi diabetes melitus sebesar $5,11 \%$ didapatkan bahwa perempuan lebih berisiko untuk menderita DM dibanding laki-laki yaitu 1,33 kali dibanding laki-laki.

Berdasarkan hasil hasil analisis univariat IMT menunjukkan bahwa berat badan normal dengan berat badan resiko obesitas tidak jauh berbeda yaitu sejumlah 14 orang dan 13 orang. Hasil uji statistik pada kelompok intervensi I dan intervensi II didapatkan ada pengaruh BMI terhadap kadar glukosa darah 2 jam setelah makan. Timbunan lemak bebas yang tinggi dapat menyebabkan meningkatnya free fatty acid (FFA). Peningkatan FFA akan menurunkan translokasi transporter glukosa ke membran plasma, dan menyebabkan terjadinya resistensi insulin pada jaringan otot dan adipose (TeixeriaLemos dkk, 2011).

Hasil penelitian diperoleh bahwasanya responden sedikit lebih banyak dalam berat badan normal dibanding dengan berat badan dengan resiko obesitas. Namun dari hasil wawancara rata-rata responden mempunyai riwayat dengan obesitas sebelumnya dan juga sesuai dengan teori pemberian injeksi insulin bahwa pemberian insulin salah satunya dilakukan apabila terjadi penurunan berat badan yang cepat. BMI yang masuk kategori resiko obesitas dan obesitas perlu diwaspadai karena obesitas merupakan faktor 
risiko yang berperan penting terhadap DM. Orang dengan obesitas memiliki masukan kalori yang berlebih. Sel beta kelenjar pankreas tidak mampu untuk memproduksi insulin yang cukup untuk mengimbangi kelebihan masukan kalori. Akibatnya kadar glukosa darah akan tinggi yang akhirnya akan menjadi diabetes melitus.

Hasil penelitian ini sesuai dengan penelitian yang dilakukan Irawan 2010,orang yang mengalami kegemukan memiliki risiko 2,11 kali, sedangkan orang yang mengalami obesitas berisiko 3,46 kali untuk menderita DM dibanding orang yang tidak mengalami kegemukan. Orang yang mengalami obesitas sentral berisiko 2,63 kali untuk menderita DM dibanding dengan orang yang normal. Menurut penelitian Trisnawati, Setyorogo (2013) individu yang memiliki obesitas lebih berisiko 7,14 kali untuk mengalami diabetes dibandingkan dengan individu yang tidak obesitas.

Hasil penelitian univariat sebagian besar responden pada kedua kelompok intervensi adalah dengan riwayat hipertensi. Hasil uji statistiktidak ada pengaruh riwayat hipertensi terhadap kadar glukosa darah 2 jam setelah makan yang diberikan injeksi insulin 0-10 menit dan 11-20 menit.

Hipertensi akan menyebabkan penebalan pembuluh darah arteri sehingga pembuluh darah akan menyempit dan nantinya akan mengganggu pengangkutan glukosa dari dalam darah (Zieve, 2012). Disfungsi endotel merupakan salah satu patofisiologi umum yang menjelaskan hubungan yang kuat antara tekanan darah dan kejadian DM tipe 2.

Hasil penelitian sesuai denga teori bahwasanya responden dalam penelitian lebih banyak dengan riwayat hipertensi, namun saat dilakukan penelitian peneliti tidak mengukur tekanan darah dan tidak mempertimbangkan penggunaan obat anti hipertensi. Penelitian yang dilakukan Trisnawati, Setyorogo (2013) dari 50 orang diperoleh 22 $(81,5 \%)$ responden dengan hipertensi. Hasil uji statistic ada hubungan yang bermakna antara tekanan darah dengan DM tipe 2. Orang yang terkena hipertensi berisiko lebih 6,85 kali lebih besar untuk menderita diabetes dibanding orang yang tidak hipertensi. Penelitian Rajasa (2016) dari 73 responden didapatkan sebanyak 51 responden atau $69,9 \%$ dari total responden, sedangkan yang tidak menderita hipertensi sebanyak 22 responden.

Hasil penelitian infeksi menunjukkan pasien infeksi kelompok intervensi I dan intervensi II sebanyak 17 orang. Hasil uji statistic analisis bivariat menunjukkan bahwa tidak ada pengaruh infeksi terhadap kadar glukosa darah 2 jam setelah ,makan yang diberikan injeksi insulin 0-10 menit dan 11-20 menit.

Hipergilkemi menyebabkan gangguan aktivitas leukosit dan menimbulkan respon inflamatorik sehingga menyebabkan viskositas darah meningkat dan membentuk trombus terutama pada mikrovaskuler, hal ini mengakibatkan terjadinya kerusakan pada pembuluh darah mikro sebagai gejala gangguan sirkulasi di jaringan perifer (Jokela, 2009). Pada beberapa penelitian disebutkan bahwa terjadi gangguan kemotaksis lekosit dan fagositosis pada penderita diabetes melitus, terutama selama hiperglikemia dan ketoasidosis diabetik (Hay, 2010).

Penelitian yang dilakukan oleh Oktavia (2014) pada pasien DM tipe 2 menyatakakan sebanyak 74,1\% memiliki jumlah leukosit yang tinggi. Hasil RP dapat diketahui bahwa penderita Diabetes Melitus akan memiliki risiko 0,77 kali lebih tinggi untuk mengalami peningkatan jumlah leukosit dari pada bukan penderita Diabetes Melitus (Oktavia, 2014).

Rata-rata hasil glukosa darah pada kelompok intervensi I sebelum makan $(234,88 \pm 79,68)$ dan 2 jam setelah makan $(246,94 \pm 76,76)$. Selisih rata-rata kadar 
glukosa darah intervensi I yaitu $(12,06 \pm 3,96)$. Kelompok intervensi II rata-rata glukosa darah sebelum makan $(234,12 \pm 80,86)$ dan 2 jam setelah makan $(252,35 \pm 78,79)$. Selisih rata-rata kadar glukosa darah intervensi II $(18,24 \pm 4,97)$. Hasil uji statistik pada kadar glukosa darah sebelum makan dan 2 jam setelah makan pada kelompok intervensi I diperoleh perbedaan kadar glukosa darah sebelum dan sesudah intervensi. Hasil uji statistik selisih kadar glukosa intervensi I dan intervensi II diperoleh perbedaan selisih glukosa darah kelompok intervensi I dan Intervensi II.

Dalam keadaan normal kadar gula darah melakukan fungsinya membutuhkan insulin yang dikeluarkan oleh sel-sel beta dalam pankreas. Insulin berfungsi dalam mengendalikan kadar gula darah dengan cara mengatur dan penyimpanannya (Rahcmawati, 2015). Salah satu hal penting dalam evaluasi pasien DM adalah kontrol glikemik. Kontrol glikemik yang ketat akan meningkatkankeberhasilan pengelolaan DM dan dapat dipantau dari kadar glukosa darah. Selain itu juga dapat dipakai sebagai pegangan dalam penyesuaian diet, latihan jasmani dan obat-obatan untuk mencapai kadar glukosa senormal mungkin sehingga terhindar dari hiperglikemia maupun hipoglikemia (Perkeni, 2015).

Dalam penelitian ini dilakukan pemeriksaan kadar glukosa sewaktu dan glukosa 2 jam setelah makan (2PP). Pemeriksaan kadar postprandial adalah pemeriksaan kadar gula darah yang dilakukan saat 2 jam setelah makan. Pemeriksaan ini bertujuan untuk mendeteksi adanya DM atau reaksi hipoglikemik (Tandra, 2013). Sedangkan pemeriksaan kadar gula darah sewaktu adalah pemeriksaan gula darah yang dilakukan setiap waktu, tanpa ada syarat puasa dan makan. Pemeriksaan ini dilakukan untuk mengatasi permasalahan yang mungkin timbul akibat perubahan kadar gula secara mendadak (Utami, 2012 dalam Rachmawati, 2015).

Pengendalian glukosa darah dengan obat anti diabetes salah satunya dengan pemberian injeks insulin. Insulin analog kerja cepat (rapid-acting) memiliki penyerapan di subkutan yang lebih cepat, puncak kerja yang lebih singkat dan tinggi serta masa kerja yang juga lebih singkat. Insulin analog merupakan jenis insulin yang baik karena memiliki profil sekresi yang sangat mendekati pola sekresi insulin normal atau fisiologis (Rismayanthi, 2011). Insulin kerja cepat (rapid acting insulin) dimana ketika dilakukan injeksi, insulin akan mencapai darah dalam waktu 5-15 menit kemudian akan mencapai waktu puncak 1 sampai 2 jam dan dapat bertahan selama 4-6 jam. Akibatnya waktu pemberian menjadi lebih dekat dengan waktu makan, bahkan dapat diberikan saat makan (Perkeni, 2015).

Ketidaktepatan waktu penyuntikan insulin dengan pasien mengkonsumsi makan, maka akan menyebabkan fluktuasi glukosa darah yang berakibat kepada hiperglikemia dan hipoglikemia. Kejadian hipoglikemia pada pasien dengan insulin bervariasi antara 6\% sampai dengan $64 \%$ dengan nilai kadar glukosa darah 3,0-3,1 mmollL (Kann, Wascher, \& zackova, 2006).

Injeksi insulin dilakukan di lokasi yang mempunyai banyak lemak subkutan (adiposa), oleh karena teknologi yang digunakan oleh preparat insulin memerlukan lemak untuk dapat didistribusikan dengan baik ke dalam darah. Penyerapan insulin paling cepat terjadi di daerah abdomen yang kemudian diikuti oleh daerah deltoid, vastud lateralis dan gluteus. Penelitian yang dilakukan oleh Hansen et al, (2007) rapid acting insulin diserap $86 \%$ lebih cepat di abdomen dibanding di vantus lateralis, $30 \%$ lebih cepat di abdomen dibanding di deltoid. Penyerapan insulin di deltoid sekitar $40 \%$ lebih cepat dibanding di vastus lateralis. 
Responden yang dilakukan injeksi insulin di lokasi abdomen pada 0 menit atau bersamaan dengan makan, maka insulin akan cepat diserap oleh tubuh dan akan bekerja sejalan dengan meningkatnya kadar gula darah akibat proses metabolisme pencernaan tubuh serta akan sama-sama kembali normal 2 jam sesudahnya. Bila dilakukan pengunduran penyuntikan akan menyebabkan insulin lebih dulu bekerja dan tidak sejalan dengan peningkatan kadar gula darah akibat proses metabolisme pencernaan tubuh, akibat lebih dulu insulin bekerja, maka ia akan lebih dulu pula akan kembali normal dibandingkan kadar gula darah, sehingga kadar gula darah akan sedikit lebih tinggi pada 2 jam setelah makan. Temuan yang didapat dalam penelitian ini, di mana penyuntikan yang dilakukan bersamaan dengan makan atau 0-10 menit paling efektif untuk mengendalikan kadar gula darah 2 jam setelah makan, dibandingkan penyuntikan dengan waktu 11-20 menit sebelum makan.

Hasil penelitian yang dilakukan oleh Santoso (2014) sampel yang digunakan berjumlah 60 responden bahwa rata-rata kadar gula darah 2 jam setelah makan yang dilakukan injeksi insulin di lokasi abdomen pada waktu 0 menit adalah $133.2( \pm 18.2)$, pada waktu 10 menit sebesar $141.4( \pm 12.5)$, pada waktu 20 menit adalah $166.5( \pm 10.2)$ dan pada waktu 30 menit sebesar $183.8( \pm 7.1)$. Hasil penelitiannya menemukan ada perbedaan kadar gula darah 2 jam setelah makan penderita DM tipe 2 yang dilakukan injeksi insulin pada waktu 0, 10, 20 dan 30 menit sebelum makan. Penyuntikan pada waktu 0 menit atau bersamaan dengan makan secara signifikan lebih efektif mengendalikan kadar gula darah 2 jam setelah makan dibandingkan dengan penyuntikan pada waktu 10, 20 dan 30 menit sebelum makan.

Penelitian yang dipublikasikan Medsafe, menemukan, injeksi insulin jenis NovoRapid $(0,15 \mathrm{U} / \mathrm{kg})$ segera sebelum makan lebih efektif dalam penurunan kadar gula darah dibandingkan dengan penyuntikan 30 menit sebelum makan (Medsafe, 2012). Hasil Peneltian Yoeri M. Luif et al, (2010) sebanyak 10 sampel diuji coba diperoleh insulin aspart yang diberikan 30 menit, 15 menit atau 0 menit sebelum makan yang diinjeksikan dideltoid. Hasil 30 menit sebelum makan (11.74 $\pm 0.80 \mathrm{mmol} / \mathrm{l}), 15$ menit $(9.26 \pm 0.72 \mathrm{mmol} / \mathrm{l})$ dan 0 menit $(12,29 \pm 0.93 \mathrm{mmol} / \mathrm{l})$. Hasil uji statitisk secara signifikan terdapat perbedaan kadar glukosa darah post prandial. Pemeberian insulin rapid acting 15 menit sebelum waktu makan menghasilkan glukosa darah yang lebih rendah. Penelitian berbeda dengan penelitian yang dilakukan oleh Erin cobry. et al. 2010, dari 23 responden dibagi 3 kelompok. Pemberian insulin 20 menit sebelum makan (Pre), segera sebelum makan dan 20 menit setelah makan (Post) menunjukkan injeksi 20 menit sebelum makan secara signifikan lebih rendah dari 0 menit dan 20 menit setelah makan. Glikemik AUC secara signifikan lebih rendah 20 menit sebelum makan disbanding segera makan dan 20 menit setelah makan. Kadar glukosa darah puncak secara signifikan lebih rendah pada 20 menit selum makan disbanding segera makan dan 20 menit setelah makan. Injeksi insulin kerja cepat 20 menit sebelum makan menghasilkan kontrol glukosa post prandial yang secara signifikan lebih baik daripada ketika makan bolus insulin diberikan tepat sebelum makan atau 20 menit setelah inisiasi makan. 


\section{SIMPULAN}

Responden terbanyak dalam penelitian ini adalah dengan jenis kelamin perempuan, rentang usia 45-65 tahun, resiko obesitas dan riwayat hipertensi.Terdapat perbedaan kadar glukosa darah sebelum makan dan 2 jam setelah makan dengan pemberian waktu injeksi insulin 0-10 menit pada pasien DM tipe 2. Terdapat perbedaan kadar glukosa darah sebelum makan dan 2 jam setelah makan dengan pemberian waktu injeksi insulin 11-20 menit pada pasien DM tipe 2. Terdapat perbedaan selisih kadar glukosa darah pemberian waktu injeksi insulin 0-10 menit dan waktu injeksi insulin 1120 menit. Waktu injeksi insulin yang lebih efektif adalah 0-10 menit. Ada pengaruh variabel IMT terhadap kadar glukosa darah 2 jam setelah makan pada pasien DM tipe 2 dengan pemberian injeksi insulin 0-10 menit dan injeksi insulin 11-20 menit.

\section{SARAN}

Bagi perawat diharapkan dapat meningkatkan pengetahuan dan sikap dalam pelaksanaan waktu injeksi insulin yang tepat kepada pasien DM tipe 2 dengan penggunaan insulin rapid acting. Perawat diharapkan dapat memberikan insulin sesuai dengan waktu dan jenis insulin yang diberikan.Bagi kepala ruangan dan manager keperawatan diharapkan dapat mensosialisasikan melalui edukasi, diskusi dan seminar tentang pemeberian waktu injeksi insulin rapid acting serta membuat prosedur injeksi insulin rapid acting. Penelitian ini dapat dijadikan sebagai bahan perkembangan ilmu pegetahuan keperawatan kepada mahasiswa. Penelitian ini dapat dijadikan sumber informasi dan bahan praktik kepada mahasiswa dalam pemberian asuhan keperawatan kepada pasien DM tipe 2. Penelitian selanjutnya disarankan untuk mempertimbangkan variabel lain yang mempengaruhi kadar glukosa darah pasien DM tipe 2 serta lebih mengontrol variabel-variabel tersebut diantaranya dosis insulin, hipertensi, infeksi, kecemasan. Penelitian selanjutnya untuk mempertibangkan pemeriksaan glukosa darah menggunakan analyzer. 


\section{DAFTAR PUSTAKA}

American Diabetes Association (ADA). (2018). Standar of Medical Care in Diabetes Mellitus. (M. Matthew C. Riddle, Penyunt.) Diabetes Care, vol 41, S1-S156

Black, J., \& Hawsk, J. (2014). Keperawatan Medical Bedah (8 ed., Vol. 2). (J. Mulyanto, Penerj.) Siangapore: Elsevier

Cobry E, M. K. (2010). Timing of Meal Insulin Boluses to Achieve Optimal Postprandial Glycemic Control in Patient with type 1 Diabetes. Diabetes Technol Ther, 12,173-177

Damayanti, S. (2015). Diabetes Mellitus dan Penatalaksanaan Keperawatan. Yogyakarta: Nuha Medika

Hansen, B., Grete, K., Gitte, E., Elizabeth, N., \& Hansen, G. (2007). Evidence-Based Clinical Guidelines for Injection of Insulin for Adults with Diabetes Mellitus. Denmark: Danish Nurses Organization

Hay, R. A. (2010). Bacterial Infection. dalam. Burns DA, Breathnach SM, Cox NH, Griffiths, eds. Rook's Texbook of Dermatology. London: Blachwell Publishing

International Diabetes Federation (IDF). (2017). Diabetes Atlas. International Diabetes Federation, hal. 1-145

Irawan, D. (2010). Prevalensi dan Faktor Risiko Kejadian Diabetes Mellitus Tipe 2 di Dareah Urban Indonesia. Universitas Indonesia, Fakultas Kesehatan Masyarakat. Depok: Universitas Indonesia

Jokela RM, A. J. (2009). The Effective Analgesic Dose of Dexametahasone After Laporoscopic Hysterectomy. International Anesthesia Research Society, 109, 607-615

Kann, P., Wascher, T., \& Zackova, V. (2006). Starting Insulin Therapy in Type 2 Diabetes: Twice-Daily Biphasic Insulin Aspart 30 Plus Metformin Versus OnceDaily Insulin Glargine Plus Glimipiride. Experimental and Clinical Endocrinology \& Diabetes, 527 - 532

Kementerian Kesehatan Republik Indonesia. (2014). Infodatain: Situasi dan Analisis Diabetes. Jakarta: Kementerian Kesehatan Republik Indonesia

Kurniawan, I. (2010). Diabetes Mellitus Tipe 2 pada Lanjut Usia. Majalah Kedokteran Indonesia, 60, 576-584

Luif, Y. M, V. B. (2010). Premal Injection of Rapid Acting Insulin Reduces Postprandial Glycemic Excursions in type 1 Diabetes. Diabetes Care, 33, 21522155

Medsafe. (2012). Injection Presentation. Novo Rapid NovoMix , 12

Meeto, D. A. (2010). Understanding Diabetes Mellitus and its Management. Retrieved from ebscohost: http://web.ebscohost.com/ehost/pdfviewer/

Oktavia, A. (2014). Hubungan Penyakit Diabetes Melitus dengan Kejadian Kandidiasis Kutis RSUP Dr. Soeradji Tirtonegoro . Surakarta: Fakultas Kedokteran Universitas Muhammadiyah Surakarta

Perkumpulan Endokrinologi Indonesia (Perkeni). (2015). Konsensus Pengolahan dan Pencegahan Diabetes Mellitus Tipe 2 DI Indonesia. Jakarta: PB. Perkeni

Rachmawati, C. (2015). Gambaran Kontrol dan Kadar Gula Darah pada Pasien Diabetes Melitus di Poliklinik Penyakit Dalam RSJ Prof. Dr. Soerojo Magelang. Ilmu Keperawatan Fakultas Kedokteran. Semarang: Universitas Diponegoro

Rismayanthi, C. (2011). Terapi Insulin sebagai Alternatif Pengobatan bagi Penderita Diabetes. Medikora, 6(2), 29-37 
Santoso, A. (2014). Efektifivitas Lokasi dan Waktu Injeksi Insulin terhadap Pengendalian Glukosa Darah 2 Jam Setelah Makan pada Penderita Diabetes Mellitus. Muhammadiyah Journal Of Nursing, 129-136

Soegondo, S., Soewondo, P., \& Subekti, I. (2009). Penatalaksanaan Diabetes Mellitus Terpadu. Jakarta: Balai Penerbit FKUI

Tandra, H. (2013). Segala Sesuatu yang Anda Ketahui tentang Diabetes: Paduan Lengkap Mengenal dan Mengatasi Diabetes dengan Cara Cepat dan Mudah. Jakarta: Gramedia Pusaka Utama

Teixera, L. E., Nunes, S., Frederico, T., \& Flavio, R. (2011). Reguler Physical Exercise Training Assist in Preventing Type 2 Diabetes Development: Focus on Its Antioxidant And Anti Inflamantory Properties. Biomed Central Cardiovaskuler Diabetology, 10, 1-15

Trisnawati, K., \& Setyorogo, S. (2013). Faktor Risiko Kejadian Diabetes Tipe II di Puskesmas Kecamatan Cengkareng Jakarta Barat Tahun 2012. Jurnal Ilmiah Kesehatan, 5(1), 6-11

Widodo, C. (2016). Hubungan Aktifitas Fisik, Kepatuhan Mengkonsumsi Obat Anti Diabetik dengan Kadar Gula Darah Pasien Diabetes Mellitus Di Fasyankes Primer Klaten. Surakarta: Universitas Sebelas Maret

World Health Organization (WHO). (2016). Global Report on Diabetes. Geneva, Switzerland: World Health Organization. Retrieved from www.who.int

Zieve. (2012). Hypertension. PubMed Health, 1-11 